\title{
The Impact of Economic Reform on Political Reform: Jordan as a Model
}

\author{
Mohammed Bani Salameh"1, Azzam Ananzeh², Mohammed Daradkah ${ }^{3}$ \\ ${ }^{1}$ Political Science Department, Yarmouk University, Irbid, Jordan \\ ${ }^{2}$ Journalism Department, Yarmouk University, Irbid, Jordan \\ ${ }^{3}$ Wisdom House Institute, Al Albayt University, Mafraq, Jordan \\ Email: mohammedtorki@yahoo.com
}

How to cite this paper: Salameh, M.B. Ananzeh, A. and Daradkah, M. (2018) The Impact of Economic Reform on Political Reform: Jordan as a Model. American Journal of Industrial and Business Management, 8, 1556-1586

https://doi.org/10.4236/ajibm.2018.86105

Received: March 16, 2018

Accepted: June 19, 2018

Published: June 22, 2018

Copyright (C) 2018 by authors and Scientific Research Publishing Inc. This work is licensed under the Creative Commons Attribution International License (CC BY 4.0).

http://creativecommons.org/licenses/by/4.0/

\begin{abstract}
The objective of this study is to identify the impact of economic reform on political reform in Jordan. This is achieved in three stages, commencing with developing the methodological framework of the study. This was followed by creating a theoretical scale of the relationship between economic and political reform by the use of moderating variables, which was applied to the Jordanian experience in the third and final stage of the research. The study results revealed that the economic reform (the independent variable) had a moderate impact on political reform (dependent variable) during the study period (1989-2016). The overall value of the six indices of economic reform was moderate, as was the overall value of the six indices pertinent to political reform. Based on these findings, it can be concluded that Jordan's political regime is partly free, with restricted democracy that has presently not fully matured, as it suffers from governmental and parliamentary instability, weak political participation, widespread corruption and weak governmental efficiency. The results also suggest lack of political will to achieve the desired reform and absence of an economic vision to lead the country to a better future.
\end{abstract}

\section{Keywords}

Economic Reform, Political Reform, Democracy, Jordan

\section{Introduction}

Democratic rule is the inevitable path to political development. It requires favourable and supportive socioeconomic status, characterized by some degree of economic prosperity, fair distribution of wealth, flexible class structuring with a large middle class, expansion of education and the spread of the means of com- 
munication. Presence of these elements will ultimately lead to positive political outcomes that are viewed as indicators of political development, such as political pluralism, more willingness to political participation, high level of public freedoms, governmental stability, parliamentary stability and lower level of political and administrative corruption as a result of higher level of transparency and accountability of the political regime.

Therefore, the aim of the present study is to explore the relationship between the economic reform and political reform in Jordan since the implementation of the Socioeconomic Transformation Program in 2001 [1]. This objective is met by conducting research in three distinct phases, starting with defining the methodological framework of the study, which includes hypotheses, variables and study methodology, among other aspects. The second phase is designated for the development of a theoretical qualitative scale, which could be used to measure the relationship between economic and political reform by the use of indices as moderating variables. Finally, this scale is applied to the Jordanian experience in the third phase of the study, to identify the impact of economic reform on political reform.

\section{The Methodological Framework}

\subsection{The Research Problem}

The research problem noted above, which is to explore the relationship between the economic reform and political reform in Jordan since the implementation of the Socioeconomic Transformation Program in 2001 allowed formulating the following research question: How did the Socioeconomic Transformation Program in Jordan affect political reform?

In addition, secondary questions were derived from the main question, as answering them ensured that study objectives were met. Those questions first study the impact of the Socioeconomic Transformation Program on Jordan's average per capita income.

They also look into the extent of change in middle class size and class structure as a result of the implementation of the Socioeconomic Transformation Program, and the impact of the Program on the urbanization rate (urban vs. rural residents).

Another objective is the impact of the Program on the level of education in Jordan, and the impact of the Program on the level of industrialization in Jordan. Finally, the questions look into the impact of the Program on the spread of mass communication?

\subsection{The Study Hypotheses}

The study hypotheses include the following:

1) The Socioeconomic Transformation Program led to increased political participation.

2) The Socioeconomic Transformation Program led to increased public free- 
doms.

3) The Socioeconomic Transformation Program led to increased level of transparency.

4) The Socioeconomic Transformation Program led to enhancement of political pluralism.

5) The Socioeconomic Transformation Program led to increased level of government stability.

6) The Socioeconomic Transformation Program led to increased level of parliamentary stability.

\subsection{The Study Variables}

1) Independent variable: the independent variable in this study is: The Socioeconomic Transformation Program that was announced in 2001 and implemented from 2002 to 2006, following a number of economic reform programs in the period of (1989-2001), (2002-2006), and (2006-2015).

2) Moderating variables: Those are the variables contributing to transmitting the independent variable effect to the dependent variable. These include a number of economic indices, which are:

a) Jordan's average per capita income.

b) The change in the structure and the size of the middle class.

c) The rate of urbanization.

d) Degree and level of education.

e) Extent of spread of the means of communication and mass media.

3) Dependent variable: This is the variable that measures the degree of political reform as measured by the following indices:

a) Political participation.

b) Public freedoms.

c) Level of transparency and corruption.

d) Political pluralism.

e) Government stability.

f) Parliamentary stability.

\subsection{Study Methodology}

This study was comparative in nature, as the aim was to compare the relationship between economic and political reforms in Jordan in two closely related time periods in order to detect the evolution of this relation and its impact, for the purpose of accepting or rejecting the study hypotheses. The application of this comparative methodology required that the researchers adopt different methodic procedures that first identify the indices of the economic reform as the independent variable, as described in the section The study variables then identify the main indices of political reform that would form the dependent variable, which include the political pluralism index, that contains sub-indices, such as: legislative controls of forming official and unofficial political institutions, par- 
liament, parties, trade unions, etc., and the number of political parties before and after the implementation of the Socioeconomic Transformation Program.

1) Another main index the Public Freedoms Index with sub-indices that include conventions signed by Jordan before and after the Program implementation, and extent of spread of the means of communication and mass media. There is also the Political Participation Index that includes the Electoral Law, and the number and effectiveness of public and youth reform movements and demonstrations. Another index is the Government Stability Index that includes ministerial reshuffle and formation, while the Parliamentary Stability Index includes the number of times the National Assembly was dissolved, and stability and change of blocs in the National Assembly, and finally there is the Transparency and Corruption Index, which includes the Effectiveness of the Anti-Corruption Commission.

2) Comparison is achieved through several procedures, which includes coring the indices of the independent variable of economic reform during the period immediately preceding the implementation of the Socioeconomic Transformation Program, i.e., 1989-2002, and scoring the indices of the dependent variable of political reform during the period immediately following the Program implementation, i.e., 2002-2016. They also include scoring the indices of the dependent variable of political reform during the period immediately preceding the implementation of the Socioeconomic Transformation Program, i.e., 1989-2002, and scoring the indices of the independent variable of economic reform during the period immediately following the Program implementation, i.e., 2002-2016. Finally, there is comparison of the different scores of the dependent and independent variables during the two periods of time (1989-2002 and 2002-2016) to identify differences in order to prove or annul the relationship between the dependent and independent variables and thus elucidate the impact of economic reform on political reform in Jordan. This assisted in subsequent exploration of the enabling and impeding factors.

\subsection{Study Limitations}

The study was affected by several spatial and temporal limitations pertinent to the Jordanian experience of economic and political reform from 2002 to 2016, which includes the implementation of the Socioeconomic Transformation Program in Jordan, which commenced in 2002. Owing to the official and public controversy associated with this Program research focus was solely on the association between economic and political reform in Jordan while the substantive limits of this study are to research the impact of economic reform indices on political reform indices during the 2002-2016 period.

\subsection{Study Significance}

The study holds a number of significances, which first include the scientific significance: This study presents an attempt to scientifically explore the relation- 
ship between economic reform and political reform, as one of the contemporary phenomena of interest to the political regimes and academic researchers in the field of political economy. This is particularly pertinent in light of the reform and Structural Adjustment Programs (SAPs) offered to certain developing countries by international economic institutions, such as the International Monetary Fund (IMF) and the World Bank. Another significance is the Practical Significance through which the authors sought to uncover the impact of economic reform in Jordan on democratic transition, especially under the implementation of the Socioeconomic Transformation Program during the study period. The study aim in this respect was to assist the institutions responsible for political and economic decision making in identifying areas of defective implementation of the Program and ascertain the extent to which it achieved desired outcomes. These findings could be utilized to adjust the general reform policy in Jordan in accordance with a clear-cut strategy aimed at a sustainable and overarching development.

\subsection{Study Concepts and Terminology}

1) Political Reform: This concept is related to the political development and is often used interchangeably with other synonymous concepts, such as political adaptation, political modernization, political development, political openness, political transition and democracy.

The common factor among all those concepts is democracy as the ultimate goal, whereby each concept might be descriptive of certain links in the chain toward the State being ranked as a democratic state. In this sense, democracy is the goal of political development, whereby the latter represents the process aiming to establish a stable regime characterized by legitimacy and effective leadership that ensures growth and development of the political system's capacity of mobilizing financial and human resources [2]. Thus, the operational definition of democracy and the synonymous definitions of political reform encompass the following indices [3]:

a) Periodic free and fair elections

b) Self-reliant lobbies that are not under control of the government

c) Independent media

d) The three powers are separate and in balance

e) Peaceful and periodic power rotation

f) Judiciary and constitutional system that safeguards justice and rule of the law

g) Civil rights and freedoms: freedom of thinking, expression, media, participation, access to information, and right of assembly and association

2) Economic Reform: The sum of the actions taken by the various economic authorities intending to improve the performance of economic activity in the state. Distinction between the economic stability or stabilization policies on one hand, and the reform or structural adaptation policies on the other is that the 
former responds to the short-term economic factors such as inflation rate, the balance of cash reserves, using all monetary and financial means to adjust the overall level of demand and the its rate of growth.

The second term, however, pertains to facing the imbalances that hinder the long-term growth, such as deviation in production incentives, especially in light of the worsening debt size of the state and the slowdown in the economic growth.

The operational definition of Economic Reform by IMF conditionality includes the following indices [4]:

a) Reducing budget deficit and debt

b) Referring to the real price by liberalization of internal prices, wages and exchange rates

c) Abolition of commodity subsidies

d) Strengthening the private sector and increasing its participation in running the economy

e) Foreign trade liberalization

3) The Socioeconomic Transformation Program is a program aiming to accelerate the growth and developmental processes in order to reduce poverty and stimulate the private sector growth through privatization and improving the work environment for increased private investment rate.

The researchers' main area of interest is the extent to which the Socioeconomic Transformation Program in Jordan has contributed in the economic indices as moderating variables. These comprise of factors deemed as the primary conditions for the transmission of the impact of the independent economic variable to the dependent variable of political reform, and its indices to achieve political development represented by a democratic state during the study period. This is illustrated by the chart below Figure 1 .

\section{Literature Review}

Studies related to the relationship between economic variables and the political variables can be classified into two types:

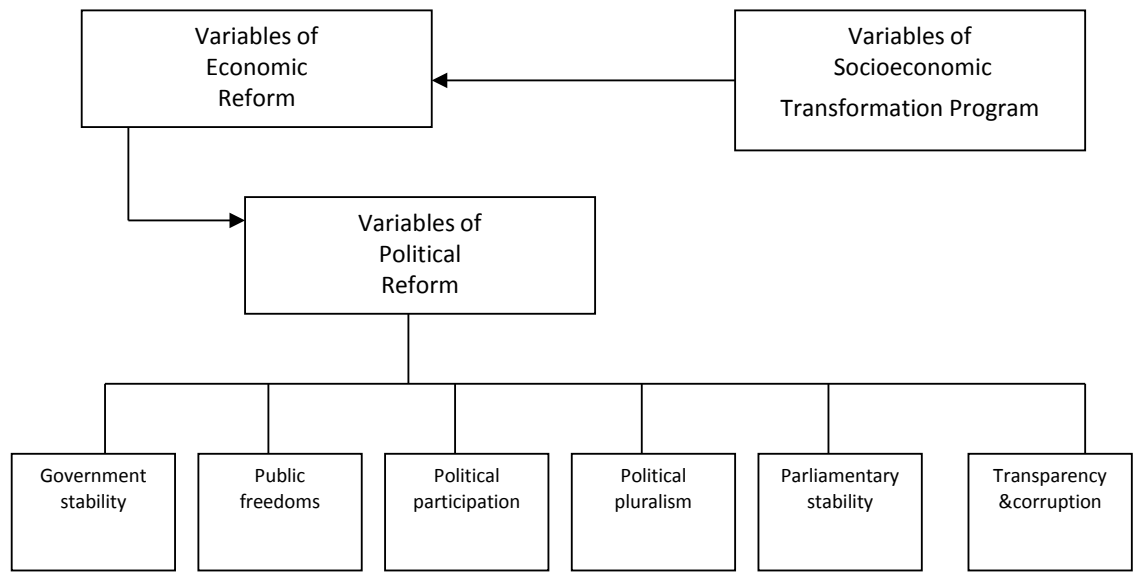

Figure 1. Variables of Economic, Socioeconomic \& Political Reform. 
A: Empirical studies, where the aim is to establish the impact of economic factors on the quality of political regime and level of democracy in several political regimes in different countries. Findings of such studies have affirmed the role of economic factors and economic growth in achieving democracy at a later stage. Authors of several studies of this type confirmed presence of a positive relationship between economic variables as increased levels of industrialization, per capita income, urbanization, education and mass communication and the political participation as one of the indices of political development. Some of these studies are explored below in more detail.

1) Lipset's study [5] confirmed presence of a linear relationship between socioeconomic development and democratic development. In this work, economic development included level of industrialization, urbanization, high educational levels and the steady increase in the total wealth. This was established through studying four categories of countries, comprising of European and English speaking stable democratic countries, European and English speaking unstable and dictatorial countries, Latin American and unstable dictatorial countries, and Latin American and stable dictatorial countries.

2) Colman discussed the relationship between the level of economic development and the nature of political regime in terms of being competitive, semi-competitive or authoritarian. In this research, the author rated 75 developing countries according to democracy in the late 1950s [6].

3) Pye investigates the role of means of mass communication in enhancing democracy across 21 comparative political regimes in 1988, he came to conclusion that media plays an important role in consolidating democracy [7].

4) Deutch analysed the relationship between economic growth and national unification. He tried to provide answers to questions such as: what is the relation of nationality to economic life, to income, opportunities, and expectations? And how it become so important to individuals as to override their economic interest to self-preservation? [8]

5) Lerner alternatively focused on urbanization, education and spread of media and communication. This study's findings revealed that democratic development in the Middle Eastern countries strengthens education, which in turn accelerates growth in media outlets thus contributing to democratic development [9].

6) Russet investigated the association between average per capita income and the nature of political regimes in 89 countries. According to Russet countries with higher average per capita income tended to have competitive regimes while those with average per capita income were more or less semi-competitive and countries with low per capita income had dictatorial regimes.

As a part of his investigation the author also discussed the association between income and growth of democracy in countries with per capita income lower than 1000 USD. This was achieved through 1335 observations covering 1950 to 1999 period, revealing that the countries included in the assessment experienced 142 years of democracy. On the other hand, 880 annual observations of coun- 
tries with per capita income exceeding 8000 USD showed that they experienced 147 years of dictatorship. In conclusion, the author highlighted the following findings:

a) Democracies are not affected in poor countries but rather in countries with average per capita income. In addition, economic development is not conducive to democracy in dictatorial countries that became rich.

b) Dictatorships were more likely to stay in power when the economy grew or declined within 1 - 3 years. Some dictatorships collapsed after a period of economic growth, while some have collapsed after many years of economic stagnation.

c) The effect of income distribution demonstrated that dictatorships thrive when there is a significant inequality in income distribution and low industrialization.

d) There are other factors affecting democratic growth besides economic factors, including political history, linguistic and ethnic homogeneity, as well as existence of multiple religions and colonial heritage.

e) In countries where per capita income is less than 1001 USD the life expectancy of democracy is 12 years, whereas it is 27 years in countries where per capita income ranges between $\$ 1001$ and $\$ 3000$. Life expectancy of democracy is 60 years in countries where per capita income ranges between $\$ 3001$ and $\$ 6055$. When per capita income exceeds $\$ 6055$ democracy is expected to be sustained in the long term [10].

B. Studies on weakness and existence of a relationship between economic development and democracy growth. Some examples are discussed below.

1) Neabauer confirmed the absence of a linear relationship between the level of economic growth and that of democracy. The association between the two variables was not sustainable, however, as it ceased to exist at certain point [11].

2) Doucouliagos \& Ulubasoglu who investigated the relationship between democracy and economic growth confirmed the effect of democracy on economic growth. The researchers analyzed 91 extant studies, 10 of which showed the impact of democracy on economic growth. The study findings are summarized below:

a) There is an indirect relationship between democracy and economic growth, as evidenced by human capital formation, level of economic freedom, inflation, political instability and government spending and less liberal international trade.

b) Democracy does not affect the economic growth in all countries; the effect is strong in Latin American countries, while it is weak in Asian countries [12].

The aforementioned studies reveal that economic reform and political reform are in reciprocal correlation with interchangeable positions and impact, where democratic reform represents the independent variable that leads to the achievement of economic reform as a dependent variable. However, this link cannot be generalized to all political regimes and can exhibit temporal changes even within the same regime.

Therefore, in this work, the researchers seek to ascertain the impact and na- 
ture of the relationship between the dependent and independent variables within Jordan, focusing on the period following the implementation of the Socioeconomic Transformation Program (from 2002 until 2015) by creating a qualitative scale (described in Section 2) to examine this relationship.

\section{Creating Qualitative Scale of the Relationship between Economic Reform and Political Reform}

The researchers believe that creating a qualitative scale of the relationship between economic and political reform can be successfully achieved through the following operational steps:

1) Analysis of the literature regarding the relationship among economic growth, political development and democracy.

2) Envisioning timeline of the economic progress in Jordan to highlight the influencing factors within the indices framework of the Socioeconomic Transformation Program.

3) Creating democracy indices based on the currently available approved international scales, such as those of the Freedom House or Economist magazine.

\subsection{Relationship between Economic Development and Democracy}

Democracy is affected by a wide range of factors that can be classified at two main levels. At the macro-level, with several factors pertaining to national unity, legitimacy and accomplishment, and political culture. In terms of the social structure and socioeconomic development, there are significant indices that include civil society, the State and society, political institutions, religious and ethnic conflicts, the military institution, and international influences.

At the micro-level, the factors affecting democracy include individual factors of political elites in terms of their background, values, knowledge and preferences. The foregoing indicates that the degree of success in achieving political development and democracy is affected by a number of factors that are not solely limited to those in the economic realm. Socio-economic development is further affected by cultural, political and structural factors such as modernization, religion, civilization, institutions and type of political regime. In sum, the relationship between democracy and economic development takes one of the following forms: [13]

1) Economic development precedes democracy. This model is supported by the Modernization Theory, where the relationship between the two phenomena is linear and positive as illustrated below:

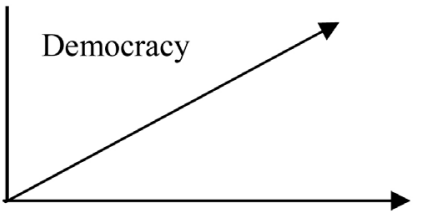

Economic progress 
2) The Political Change Theory, postulating that democracy is attained through economic development in its initial stages. The relationship is therefore non-linear, as depicted below:

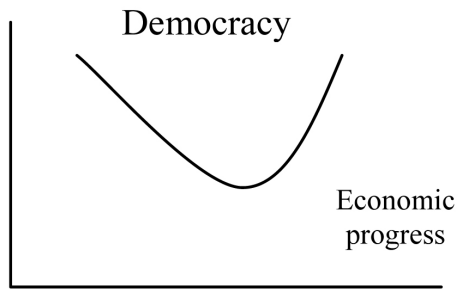

3) Economic development does not lead to democracy; hence, there is no linear relationship between the two, as shown below:

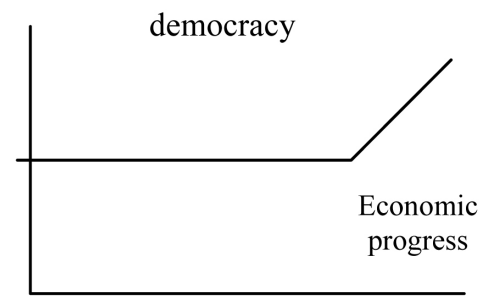

4) Democracy affects the economic development and takes the form below, derived from the case of India:

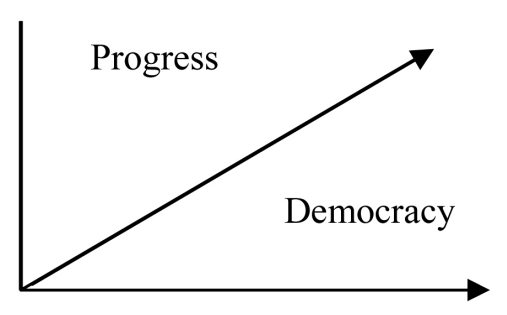

5) Democracy does not affect the economic development and takes the following form, as in the Chinese and Singaporean models:

\section{Progress}

\section{Democracy}

Upon reviewing the above graphs showing the interplay between democracy and economic development, it can be said that this relationship takes one of three forms: economic development and democracy are an independent and dependent variable, respectively. In other words, democracy is unachievable unless 
a number of conditions are met, most importantly economic growth, along with provision of education, healthcare and civic culture. This link was confirmed by the modernization and political development theories put forth in the 1960s and 1970s. Another form is where democracy is considered an independent variable and development as the dependent variable. This interrelationship implies that democracy is a prerequisite to achieving development. This view prevailed in late 1980s and was supported by the thesis of good governance put forth by the international development agencies and institutions. The third school of thought not only discusses the sequence issue, but rather purported that development in its essence is indeed freedom, whereby concern about freedoms and democracy is not only important for achieving development, but also for involving crucial relevance to the concept of human freedom in general, as discussed by Sen [14].

The review of extant literature on the relationship between democracy and economic reform summarized above enabled the researchers to make the following conclusions:

1) A linear relationship between economic reform and democracy does not exist, irrespective of which one is assumed to be dependent/independent variable.

2) Theories and studies on the relationship between economic reform and democracy are diverse. In the 1960s and 1970s it was believed that economic reform preceded democracy and this view was adopted in the development and political modernization school of thought. However, most of the studies and theories put forth since the 1980s have endorsed the simultaneousness of political reform and economic reform. Thus, studying the Jordanian experience is paramount and requires reviewing the temporal progress of Jordan's economy.

\subsection{Economic Progress in Jordan over Time}

In examining the progress of Jordan's economy over time, the researchers do not intend to elaborate on the numerical indices and other details, but rather strive to identify the major trends in order to ascertain the degree of economic vulnerability that contributed to the adoption of the economic transformation program through successive time periods. The main features characterizing Jordan's economy are: [15]

Limitation of natural and human resources. Limited natural resources, namely energy and water, are attributed to restrictions in the planned projects targeting the two areas by the political regime. Limited human resources stem from the low rate of public participation in the labour force and high dependency ratio. The third feature is the major dependence on the outside world in terms aid size and external borrowing, in addition to the chronic deficit in the budget, the huge trade balance deficit and the dominance of the service sector in the GDP, where the average was $67.5 \%$ during the $1970-2000$ period. The fourth feature is the high propensity for consumption, representing 105.9\% of GDP in 2000.

Jordan's economy passed through the following stages: [16] 
1) Post-World War II stage (1945-1961), where the unemployment rate reached $60 \%$ of the total population due to tripling of the population size as a result of the 1948 war and over-dependence on foreign aid, mainly from Britain.

2) Planning and economic development stage (1962-1966), when major industries, such as cement and phosphate, had emerged. Nevertheless, the 1967 war leading to the occupation of West Bank in Palestine had a significant impact on Jordan's economy.

3) Recession, declination and instability stage (1967-1973), characterized by a decline in Jordan's economy due to accommodating 400,000 citizens from the West Bank and the Gaza Strip.

4) Recovery and prosperity stage (1974-1982) as a result of the increase in oil prices, which consequently increased foreign aid and the accommodation of Jordanian labour in the Gulf Countries.

5) Deflation and decline stage (1983-1988) stemming from the decrease in oil prices and reduction of foreign aid as well as money transfers by workers abroad. Consequently, by late 1980s, Jordan's economy was suffering from instability, imbalance and deficiencies, including:

a) Deficit in the State's budget exceeding $20 \%$ of the GDP, with the exception of foreign grants.

b) Increase in the current account deficit in terms of diminishing Central Bank reserves of foreign currency eventuating in depletion early in 1989 and inability of the Bank to maintain the Jordan Dinar exchange rate.

c) Rise in the inflation rate to more than $25 \%$.

d) Increased ratio of internal and external indebtedness to GDP.

e) Continuing rise in unemployment rates.

6) Economic reform stage, from 1989 until 2016. The economic indices between 1989 and 1990 were as follows:

a) The budget deficit in 1990 was 143 million USD, representing 3.7\% of the GDP.

b) Arab aid to Jordan from Saudi Arabia, Morocco, Iraq, UAE, Algeria, Qatar and Libya was declined from 1,250,000 JD to 463,321 JD.

c) Decrease in GDP and economic growth rate, which accounted for $4.7 \%$ in 1989.

d) Increased deficit in the trade balance, whereby the ratio of importation to GDP in 1989 was approximately $51.8 \%$.

The researchers believe that those indices prompted Jordan to adopt the Structural Adjustment Program with the international financial institutions, namely World Bank and International Monetary Fund (IMF), in 1989-1993, 1994-1998, 1999-2001, 2002-2005 and 2006-2016.

This temporal analysis of the development of Jordan's economy reveals a high degree of vulnerability resulting from its dependence on foreign support focusing on the service sector rather than seeking to develop the agriculture, industry, energy and water sectors. It was also adversely affected by penchant for con- 
sumption rather than for saving, failure to invest in human and natural resources and the chronic deficit in the State budget, trade balance and balance of payments. This confirms the main features mentioned earlier, where the temporal progress of Jordan's economy takes the following form Figure 2.

\subsection{Creating Democracy Indices}

Achieving democracy is one of the main objectives of political reform. There are multiple scales that can be used to assess presence and degree of democracy. While Diamond referred to those scales in his work, he did not qualitatively apply them to establish the score of democracy practiced by different political regimes [17]. Thereafter Freedom House created indices, which were divided into two sets.

The first pertained to political rights, including the electoral process of pluralism, political participation and government performance. Three core questions were designed for the first index and four for the second index, while three pertained to the third one. A value of zero indicates lack of accomplishment in the corresponding core question, while a value of 4 indicates the highest accomplishment.

The second set of democracy indices represents the civil freedoms: freedom of expression and belief (4 questions), the right of association (3 questions), the rule of law (4 questions), and individual rights and safety (4 questions). The researchers then converted the primary scores of each sub-index into a scale of values ranging from 1 denoting the highest level of accomplishment to 7 as the least accomplishment. Democracy index was thus represented as the average of the summation of the scores for the two sub-indices. This methodology allowed countries to be grouped in the following categories: [18]

1) 1 - 2.5: Free Country

2) 2.5 - 5.5: Semi-free Country

3) >5.5: Not a free Country

The Economist magazine democracy index measured the following:

1) Electoral process and pluralism: Free, fair and competitive elections (12 sub-indices)

2) Civil rights: Freedom of expression and speech, freedom of the media, freedom of belief, freedom of association and assembly, fair and impartial judiciary and protection of the rights of individuals and minorities (17 sub-indices).

3) Government performance (14 sub-indices)

4) Political environment and democracy (8 sub-indices)

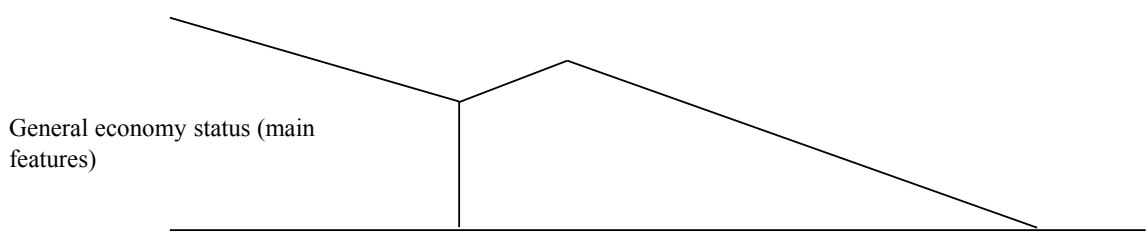

Figure 2. Stages of Jordan's Economy Progress. 
5) Political participation: Participation in political discussions, casting votes in elections and regular membership in parties (9 sub-indices) [19].

Based on the results pertaining to the aforementioned indices, score could be computed for each group on a scale from 0 to 1 , where 1 corresponds to each affirmative answer for each sub-index, $0=$ "No" and $0.5=$ "Not Sure". The scores of the five groups can then summed up and the average represents the Democracy Index ranging from 1 to 10 . This allows countries to be classified as follows:

1) Mature and full democracy: 8 - 10 points

2) Flawed democracy: 6 - 8 points

3) Hybrid ruling regime: 4 - 6 points

4) Authoritarian ruling regime: $<4$ points

Based on the aforementioned scales, the researchers can create a scale for the main and sub-indices of democracy in Jordan, as shown below:

1) Political pluralism index, which includes legislative controls to establish parties, trade unions and party activities

2) Public freedom index, which includes Conventions signed by Jordan and the extent of spread of mass communication means

3) Political participation index, which includes Electoral Law, demonstrations, public and reformist movements, public assembly law, State Security Court, penal code and law of press and publications

4) Government stability index, which includes ministerial reshuffling and political elite circulation rate

5) Parliamentary stability index, which includes the Parliament dissolution and stability of parliamentary blocs

6) Transparency index, pertaining to access to information and effectiveness of the Anti-Corruption Commission

Based on the approach described above, the researchers can create an economy development scale with the following indices as moderating variables:

1) Jordan's average annual per capita income

2) The change in the class structure (the middle class size)

3) The urbanization rate

4) The degree and level of education

5) The degree of industrialization

6) The extent of spread of the means of communication and mass media

\section{Assessing the Relationship between Economic and Political Reform in Jordan}

In this section, the researchers describe how the scale presented in Section II was applied to examine the relationship between economic reform and political reform in Jordan during the study period (2002-2016). The ultimate goal was to explore the degree of impact of the independent variable of economic reform on the moderating variables in the crisis to establish their impact on the dependent variable. This process was governed by the hypothesis that economic reform 
leads to the strengthening of democracy in the case of improvement in the indices pertaining to the moderating variables identified in Section II.

Application of the Scale is conducted by following the steps outlined below:

1) Determining numerical value expressing the moderating variables of economic reform, whereby a 0 indicates weak, 0.5 denotes average and 1 implies strong. Each variable was scored based on the statistical data derived from pertinent primary sources.

2) Determining numerical values of the six main democracy indices as a result of political reform through the following:

a) Determining the numerical value for each sub-index on a 0 - 1 scale, where 0 indicates weakness, 0.5 implies average and 1 denotes strong.

b) Calculating the sum of the numerical values pertaining to all sub-indices of the main democracy index.

c) Calculating the sum of the numerical values of all main indices resulting from the previous step before calculating their average in order to:

i) Classify Jordan's political regime according to the Freedom House scale as free, semi-free or not free

ii) Determine the quality of democracy in Jordan according to the Economist magazine scale, i.e., to elucidate whether it is mature and full, flawed, hybrid or authoritarian

3) By comparing the results obtained from the overall economic reform score with the overall political reform score, the hypothesis indicating that economic reform has led to political reform in Jordan can be tested, whereby it is either accepted or rejected.

In describing the implementation of the aforementioned process, the section is divided into two parts, whereby the moderating variables of economic reform required to transmit the impact of the independent variable to the dependent one are scored first, before calculating the scores pertaining to the main and sub-indices and variables of democracy.

\subsection{Scoring the Moderating Variables of Economic Reform Average Annual Per Capita Income in Jordan}

The progress of average per capita income in Jordan can be elucidated by examining the data presented in Table 1 below.

The table above shows that the average annual per capita income was growing throughout the years of the Economic Reform Program (1989-2016), accompanied by a relative stability in the inflation rate and economic growth rate. Thus, this index was given the score of 0.5 (average).

\subsection{Change in the Class Structure and Middle Class Size}

A family is considered middle class when its annual per capita spending is at least twice as high, but not more than four times the total poverty line. The family groups of the middle class are classified by the annual per capita spending in Table 2. 
Table 1. Average annual per capita income and inflation rate in USD.

\begin{tabular}{|c|c|c|}
\hline Year & Average annual per capita income & Inflation rate \\
\hline 1989 & - & $25 \%$ \\
\hline 1990 & - & $16.2 \%$ \\
\hline 1991 & - & $10 \%$ \\
\hline 1992 & - & $5.3 \%$ \\
\hline 1993 & - & $5.0 \%$ \\
\hline 1994 & - & $4.5 \%$ \\
\hline 1995 & 1568 & $4.5 \%$ \\
\hline 1996 & - & $4.5 \%$ \\
\hline 1997 & - & $4.5 \%$ \\
\hline 1998 & 1630 & $4.5 \%$ \\
\hline 1999 & 1630 & $1.9 \%$ \\
\hline 2000 & 1680 & $2.8 \%$ \\
\hline 2001 & 1720 & $2.4 \%$ \\
\hline 2002 & 1774 & $3.2 \%$ \\
\hline 2003 & 1159 & $6.0 \%$ \\
\hline 2004 & 1209 & $5.8 \%$ \\
\hline 2005 & 1263 & - \\
\hline 2006 & 2700 & $1.2 \%$ \\
\hline 2007 & 3000 & $5.4 \%$ \\
\hline 2008 & 3800 & - \\
\hline 2009 & 4000 & - \\
\hline 2010 & 4300 & - \\
\hline 2011 & 4542 & - \\
\hline 2012 & 4852 & - \\
\hline 2013 & 1857.2 & $5.6 \%$ \\
\hline 2014 & - & $5.8 \%$ \\
\hline
\end{tabular}

*Source: Department of Statistics.

Table 2. Middle Class Size.

\begin{tabular}{cccc}
\hline Group & $\begin{array}{c}\text { Annual per capita } \\
\text { spending }\end{array}$ & Average family size & $\begin{array}{c}\text { Percent of } \\
\text { population }\end{array}$ \\
\hline Below poverty & Below 680 JD & $7.1 \%$ & $13.3 \%$ \\
Below middle class & $680-1360 \mathrm{JD}$ & $5.8 \%$ & $37.5 \%$ \\
Middle class & $1361-2000 \mathrm{JD}$ & $4.8 \%$ & $35.5 \%$ \\
Middle class group & $2001-2720 \mathrm{JD}$ & $4.5 \%$ & $41.1 \%$ \\
Rich class & $+2721 \mathrm{JD}$ & $3.9 \%$ & $8.2 \%$ \\
\hline
\end{tabular}

*Source: Department of Statistics for the years 2008, 2010, 2012, 2015.

The data presented in Table 2 indicate that middle class comprises $35.5 \%$ of the population, while rich class comprises $8.2 \%$, given that the absolute general 
poverty line is at $680 \mathrm{JD}$, i.e., the average per capita is $57 \mathrm{JD}$. Families living in poverty comprise $13.3 \%$ of the population, as measured by the proportion of individuals whose spending is below the general poverty line.

The distribution of the poverty rate indicates that it is concentrated in the governorates remote from the centers, whereby it was 31.9\% in Mafraq, $24.2 \%$ in Ma'an, $24.3 \%$ in Tafeileh, $8.3 \%$ in the capital, $11.2 \%$, in Zarqa and $11.8 \%$ in Aqaba. Moreover, 33.5\% of the total poor in the Kingdom (i.e., 263,000 out of 781,000 individuals) live in pockets of poverty (32 pockets in 2006, according to a survey of household expenditures in 2008). The relative distribution of poor Jordanian families across governorates is given in Table 3.

The data presented above confirms that the pauperization rates in all governorates have multiplied with subsequent increase in the average number of impoverished families in the Kingdom (from 1.5\% in 1988 before the implementation of the reform program to $5.4 \%$ in 2008 , two decades after the implementation).

Data given in Table 4 pertain to the poverty indices for the 1987 to 2010 period.

Table 4 shows that poverty rates in Jordan increased from 1987 through 2004 compared to the poverty indices before the Program implementation. Furthermore, the fair distribution of income through Gini Coefficient remained constant before and after the economic reform.

Table 3. Relative distribution of poor Jordanian families by governorate.

\begin{tabular}{ccc}
\hline Governorate & Pauperization in 1988 & Pauperization in 2008 \\
\hline Capital & 1.1 & 3.8 \\
Zarqa & 1.4 & 4.6 \\
Erbid & 1.7 & 6.7 \\
Mafraq & 4.8 & 7.4 \\
Balqa & 1.9 & 7.7 \\
Kerak & 1.5 & 8.2 \\
Tafeileh & 5.8 & 8.0 \\
Ma'an & 2.5 & 5.4 \\
Average in Kingdom & 1.5 & 5.4
\end{tabular}

*Source: Report of the Social Development in Jordan for 2008.

Table 4. Poverty Indices 1987-2010.

\begin{tabular}{cccccccc}
\hline Index & 1987 & 1992 & 1997 & 1997 & 2001 & 2004 & 2010 \\
\hline $\begin{array}{c}\text { Poverty line } \\
\text { Percent of population below }\end{array}$ & 148 & 261 & 313.5 & 313.5 & 312 & 436 & 814.0 \\
$\begin{array}{c}\text { poverty line } \\
\text { Number of poor in thousands }\end{array}$ & 3 & 14.4 & 11.7 & 13.6 & 13.5 & 15 & 14.4 \\
$\begin{array}{c}\text { Poverty gap } \\
\text { Gini coefficient }\end{array}$ & 0.3 & 554.5 & 538.5 & 668 & 709 & - & - \\
& 0.36 & 0.43 & 0.36 & 0.36 & 0.36 & - & 0.376 \\
\hline
\end{tabular}

Source: International Monetary fund (2011) Evaluation Report* 
Upon careful examination of the data presented above, the researchers conclude that the middle class index as one of the economic variable indices confirms that this class is diminishing in size and with an increased imbalance in the class structure of the Jordanian society upon the implementation of Socioeconomic Transformation Program. This assessment justifies giving it a score of zero, denoting its severe weakness.

Worsening of the unemployment rates in the 1998-2010 period, as evident in Table 5, explains the severe weakness of the middle class index.

\subsection{Urbanization Rate}

Based on the assumption that urbanization rate (size of urban population) is a co-factor in democratic transition, since it enhances the diversity and multiplicity of lobbyists for civil interests in the society and leads to more formation of constantly interactive and complex relationships, the researchers posit that the urbanization rate during the Socioeconomic Transformation Program is relevant to the present study, and is given in Table 6 .

The data presented in Table 6 confirm that the ratio of urbanization (urban population) to the rural population in Jordan (focusing on those aged $15-44$ and 45 - 65 years) is convergent. Indeed, this finding prompted the researchers to give an average (0.5) numerical value to the variable of urbanization, which can lead fluctuations in the status of democratic transition in response to the implementation of Socioeconomic Transformation Program.

Table 5. Unemployment rates in Jordan 1998-2010.

\begin{tabular}{|c|c|c|}
\hline Number & Year & Rate \\
\hline 1 & 1988 & 11.1 \\
\hline 2 & 1992 & 17.1 \\
\hline 3 & 1993 & 18.8 \\
\hline 4 & 1994 & 15 \\
\hline 5 & 1995 & 14.2 \\
\hline 6 & 1996 & 12.1 \\
\hline 7 & 1997 & 14.4 \\
\hline 8 & 1998 & 11.3 \\
\hline 9 & 2000 & 13.0 \\
\hline 10 & 2001 & 14.7 \\
\hline 11 & 2002 & 15.3 \\
\hline 12 & 2003 & 14.8 \\
\hline 13 & 2004 & 14.3 \\
\hline 14 & 2006 & 18.7 \\
\hline 15 & 2007 & - \\
\hline 16 & 2010 & 13.4 \\
\hline
\end{tabular}

Source: Department of Statistics, the 2010 survey of unemployment and labor force. 
Table 6. Jordanian population by urban/rural, sex and age group in 2013 .

\begin{tabular}{ccc}
\hline Age group & Urbanization rate & Rural rate \\
\hline $15-19$ & 10.6 & 11.5 \\
$20-24$ & 9.2 & 9.3 \\
$25-29$ & 7.6 & 7.8 \\
$30-34$ & 6.9 & 6.7 \\
$35-39$ & 6.3 & 6.2 \\
$40-44$ & 5.8 & 5.7 \\
$45-49$ & 4.9 & 4.3 \\
$50-54$ & 3.7 & 2.3 \\
$55-59$ & 2.9 & 2.3 \\
$60-65$ & 2.4 & 1.7 \\
+65 & 5.1 & 4.2 \\
\hline
\end{tabular}

*Source: Department of Statistics in 2013.

\subsection{Degree and Level of Education}

Findings of many extant studies affirm the horizontal and vertical expansion of education in Jordan, higher education in particular. There are 23 public and private universities in Jordan, in addition to 51 community colleges, with more than 250,000 students, accounting for $5 \%$ of the total population [20].

The education rates are given in Table 7 below.

The degree and level of education is given in Table 8 below.

Data presented in Table 7 and Table 8 reveals qualitative as well as quantitative increase in the education rate indices. However, the positivity of this increase is curbed by the high unemployment rate and low economic activity rates. It is therefore assigned a numerical value of 0.5 (average), based on the correlation between education and unemployment as essential economic variables.

\subsection{Level of Industrialization}

The level of industrialization is measured by a number of significant indices, which include the number of workers in the industrial sector and their proportion in the total number of workers in all economic sectors, the number of registered industrial companies relative to the total number of companies registered in the Ministry of Industry and Trade, the value of industrial exports, the value of industrial investments and the percentage of industrial sector contribution-in the form of manufacturing, quarrying and electricity-in the GDP.

According to the latest data issued by the Department of Statistics in Jordan for 2015, the number of workers in all economic sectors is 977,715 , of whom 212,412 work in the industrial sector, representing $22 \%$. The number of registered companies was 1,413 , with an annual capital of 89 million JD, representing $17.3 \%$ of the total number of registered companies in 2010. In 2015, the number of industrial companies reached 2,037 with a capital of 44 million JD (20.6\%), 
Table 7. Education Rates 1991-2013.

\begin{tabular}{cccc}
\hline Index & 1991 & 2001 & 2013 \\
\hline Number of students (primary education) & 926,445 & $1,173,300$ & $1,513,750$ \\
Number of students (secondary education) & 100,953 & 173,800 & \\
Number of teachers (primary) & 36,930 & 50,600 & 85,312 \\
Number of teachers (secondary) & 6,940 & 14,300 & \\
Number of university students (bachelor degree) & - & 118,657 & \\
Number of higher education students & - & 7,564 & \\
Number of schools & - & 4,999 & \\
Illiteracy rate in 1999 & - & $10.8 \%$ & \\
\hline
\end{tabular}

*Source: Ministry of Education.

Table 8. Education Level in 2013.

\begin{tabular}{ccccccc}
\hline Group & $\begin{array}{c}\text { Rate in } \\
\mathbf{2 0 1 3}\end{array}$ & $\begin{array}{c}\text { Unemployment } \\
\text { rate in 2013 }\end{array}$ & $\begin{array}{c}\text { Economic } \\
\text { activity in } \\
2013\end{array}$ & $\begin{array}{c}\text { Rate in } \\
\mathbf{2 0 1 4}\end{array}$ & $\begin{array}{c}\text { Unemployment } \\
\text { rate in 2014 }\end{array}$ & $\begin{array}{c}\text { Economic } \\
\text { activity in } \\
2014\end{array}$ \\
\hline $\begin{array}{c}\text { Illiterate } \\
\text { Below secondary } \\
\text { school }\end{array}$ & 6.8 & 0.7 & 7.6 & 6.7 & 0.6 & 7.5 \\
$\begin{array}{c}\text { Secondary school } \\
\text { Sech }\end{array}$ & 17.8 & 8.5 & 10.9 & 53.7 & 0.44 .6 & - \\
$\begin{array}{c}\text { Middle diploma } \\
\text { Bachelor degree } \\
\text { or higher }\end{array}$ & 7.8 & 10.1 & 8.5 & 17.3 & 7.2 & - \\
\hline
\end{tabular}

Source: Department of Statistics in $2013^{*}$.

while the national exports in 2011 amounted to 4,780 million JD, 88.3\% of which accounted for industrial exports worth 4,221 million JD, while this percentage was $91 \%$ in 2015 [21].

In the report, domestic investments were evaluated at 1436 million JD in 2010, declining to 729 million JD in 2015. The foreign investments, on the other hand, were estimated at approximately 295 million JD in 2010, declining to 224 million JD in 2011. Statistics also indicate a $0.3 \%$ decrease in the Index of Industrial Production during 2015 compared with 2014. This decline is attributed to the decrease in production quantities of the transformative industries by $2.2 \%$, with a relative importance of $82.5 \%$, versus increase in the production quantities of the quarrying industries by $16.5 \%$, with a relative importance of $11 \%$, and $4.5 \%$ electricity production with the importance of $6.5 \%$. With respect to the index of contribution of various industries in the GDP, the quarrying industries comprised $1.8 \%$, and the transformative industries $17.6 \%$ and $2.3 \%$, pertaining to electricity and water, respectively. Thus, based on these indices, the level of industrialization in Jordan is rated as low and is assigned the numerical value of zero.

Finally, in examining the extent of spread of the means of communication, 
mass media and information technology, we opted for the use of the Internet in the Jordanian society as an indicator of the spread of the means of communication, information and social media for the years 2008 and 2010. We noted that the rate has risen from $26 \%$ in 2008 to $27.2 \%$ in 2010 , whereby household annual Internet subscription in 2008 was $18 \%$. The age groups of the Internet users are given in Table 9.

As can be seen from the data reported above, in the Jordanian society, Internet usage is most widespread in the 20 - 34 age group. Nevertheless, spread of Internet remains average and is given the score of 0.5 .

\subsection{Scoring Political Development Indices}

\subsubsection{Political Pluralism Index}

This index includes two sub-indices, namely Legal Controls of the Electoral Law and Political Parties Law in terms of stability and change, and the number of parties. Despite the varied definitions of political pluralism, the most widely accepted is based on the existence of different political parties representing the various social, economic, cultural and political forces aiming at winning the public opinion to gain power in order to achieve their goals and agendas [22].

That is why the Parties Law and Electoral Law are viewed as legal controls. The researchers have the following remarks in this regard:

1) The rate of change in the Parties Law and Electoral Law was rapid since the beginning of implementation of the Socioeconomic Transformation Program, which coincided with the beginning of the democratic transition in 1989. For instance, the parliamentary elections took place under the Political Parties Law No. 32 of 1992, which was amended in 2007 to increase the number of founders from 50 members as per the law of 1992 to 500 members from five governorates, equivalent to $10 \%$ from each governorate. The law was amended again in 2015 , whereby the number of founders was reduced to 150. The Electoral Law was amended from a transferable single vote system in 1989 to a single vote system in 1993, introducing sub-districts and national list in 2012, followed by proportional open list in 2016.

Table 9. Age Groups of Internet Users in 2010 and 2014.

\begin{tabular}{ccccc}
\hline Age group & User 2014 & Non-user 2014 & User 2014 & Non-user 2014 \\
\hline $9-5$ & 10.4 & 89.5 & 15 & 84.4 \\
$10-14$ & 25 & 74.5 & 36 & 63.4 \\
$15-19$ & 54.9 & 52 & 63 & 36.4 \\
$20-24$ & 46.2 & 52.2 & 75.9 & 23.3 \\
$25-29$ & 33 & 65.5 & 72.2 & 27.1 \\
$30-34$ & 25.6 & 73.2 & 62.7 & 37.1 \\
$35-39$ & 25.8 & 75.6 & 55.4 & 43.7 \\
50 and above & 11.3 & 86.7 & 21.7 & 77.4 \\
\hline
\end{tabular}

Source: Department of Statistics in $2015^{\star}$. 
2) Representational disproportionality between population size and district delimitation was eliminated in 2010 by allowing a larger number of participants, as per the amended electoral system. This has resulted in the domination of the tribal and regional dimension and fragmentation of political parties' power, which comprised no more than $25 \%$ of the members of the House of Representatives.

The number of parties increased to 43 in 2016 from 31 parties in 2004 and 24 in 1992.

The researchers point out that political pluralism index is measured by the number of parties as a sign of political openness and is therefore given the numerical value of 1 . However, its effectiveness was curbed by the legal controls represented by the Parties Law and Electoral Law, due to which the proportion of party representation in the House of Representatives has declined. Therefore, the researchers would describe this index as being quantitatively strong but qualitatively weak, which reduces its numerical value to 0.5 (average).

\subsubsection{The Public Freedoms Index}

This index was characterized by fluctuation since the early 1990s through the period of implementation of the Socioeconomic Transformation Program in accordance with the laws governing the political and civil rights and public freedoms [23] as demonstrated by the indices presented and discussed in Table 10.

Jordan is rated as one of the partly-free countries (category 3 - 5), according to the United Nations Program on Civil and Political Rights, as noted in Table 11.

Upon analyzing the information tabulated above, the researchers rated the public freedoms index as average, corresponding to the numerical value of 0.5 , as one of the political reform indices throughout the implementation of Socioeconomic Transformation Program.

\subsubsection{Political Participation Index}

The political participation is defined as a group of activities that influence the political power, whether the activity is individual or collective, organized or spontaneous, continuing or intermittent, peaceful or violent, legal or illegal, and effective or ineffective. It is divided into two types, namely legal, legitimate conventional political participation, such as elections, parties and public demonstrations; and illegal participation, such as assassinations and civil disobedience.

The researchers, therefore, measured political participation using two key indices, one of which is related to the co-factors of the political participation (e.g., the emergence of new social forces), while the other pertains to violence and protesting behaviour as unconventional tools of political participation [25].

Considering the index of the emergence of social forces as expressing objection to the performance of the Jordanian political regime it can be represented as follows:

1) Labor movements, such as that pertaining to the workers in electricity, 
Table 10. Status of Public Freedoms (2000-2016).

\begin{tabular}{|c|c|}
\hline Indicator & Process \\
\hline Public Meetings Law of 2001 & $\begin{array}{l}\text { It requires obtaining a prior written approval from the Administrative Governor to organize meetings or } \\
\text { demonstrations. The former Jordanian law of } 1953 \text { demanded only sending notice to the Administrative } \\
\text { Governor. }\end{array}$ \\
\hline State Security Court Law of 2001 & $\begin{array}{l}\text { Consideration of any case, which has expanded its powers. It also abolished the right to appeal in the case of } \\
\text { misdemeanours, which confiscates the right to challenge the court decision. Additionally, it gave the Attorney } \\
\text { General the right to arrest the accused for up to two months without a trial. }\end{array}$ \\
\hline Penal Code of 2001 & $\begin{array}{l}\text { Loose provisions on and definitions of "Terrorism", consequently compromising the press freedom and } \\
\text { freedom of expression, in addition to restoring jail punishment for journalists and closing newspapers, in line } \\
\text { with the Press and Publication Law of } 1997 \text { amended by the } 1998 \text { law. }\end{array}$ \\
\hline Provisional Laws & $\begin{array}{l}\text { In absence of the House of Representatives, the number of provisional laws from } 2001 \text { to } 2003 \text { was about } 213 \text {. } \\
\text { The proceedings of the } 12 \text { lawsuits filed to refute these laws before the Supreme Court of Justice were } \\
\text { discontinued. In addition, the Jordanian Society for Human Rights was dissolved, three engineers were } \\
\text { arrested and the female activist Toujan Faisal was sentenced to three years in prison. }\end{array}$ \\
\hline $\begin{array}{l}\text { Situation of civil and political } \\
\text { rights throughout the period } \\
\text { 2004-2016 }\end{array}$ & $\begin{array}{l}\text { The establishment of the Higher Media Council pursuant to Law No. } 26 \text { of } 2004 \text {, which expanded its powers to } \\
\text { include the consideration of complaints against media representatives and enforced the civilian criminal } \\
\text { responsibility on crimes related to publishing and the inadmissibility of the imprisonment of journalists and } \\
\text { the right of access to information. } \\
\text { Trade Unions Bill 2005, which restricted the scope of the union work. } \\
\text { Press and Publications Law amendment, including the abolition of punishments of imprisonment and } \\
\text { detention in publications offences, and forwarding the draft law of the right to access information. } \\
\text { Promulgation of the National Centre for Human Rights Law No. } 51 \text { of 2006, whereby the Government ratified } \\
\text { five conventions on human rights in 2006, such as the Elimination of Racial Discrimination, International } \\
\text { Covenant on Civil and Political Rights, the Convention against Torture and the Optional Protocol to the } \\
\text { Convention on the Rights of the Child, in addition to upholding the decision to ratify Convention on the } \\
\text { Elimination to All forms of Discrimination Against Women (CEDAW) } \\
\text { Promulgation of the Prevention of Terrorism Act, the Anti-Corruption Law under which Anti-Corruption } \\
\text { Commission was established in 2007, the Press and Publications Law draft, Political Parties Law, the Financial } \\
\text { Disclosure Law draft and amending Article 3-8 of the Penal Code, where the penalty of imprisonment was } \\
\text { increased from three months to six months, and banning the use of discretionary extenuating reason. } \\
\text { The Right of Access to Information Law was approved, alongside the amendment of the Press and } \\
\text { Publications Law, after permitting arresting journalists and lifting prior censorship of publications, while } \\
\text { upholding the need for obtaining prior license as a prerequisite to issuing publications, permitting the } \\
\text { Government to hold shares in the newspapers, and amendment of the Municipal Law for the election of } \\
\text { mayors and raising the female quota to } 20 \% \text {. } \\
\text { Increased number of arrests after Jordan had joined the War Against Terrorism, which resulted in the arrest of } \\
\text { the Secretary General of the Muslim Brotherhood Zaki Bany Irsheid and other leaders, in addition to requiring } \\
\text { registration and licensing of the news websites. }\end{array}$ \\
\hline $\begin{array}{l}\text { Constitutional amendments, } \\
\text { including: }\end{array}$ & $\begin{array}{l}\text { The appointment of the Army Commander, Head of Intelligence, Gendarmerie Commander, Chairperson and } \\
\text { members of the Constitutional Court, the Supreme Judicial Court and the Senate, in addition to defining the } \\
\text { Parliament Spokesperson's term as having two-year duration [24]. }\end{array}$ \\
\hline
\end{tabular}

Source: this table was made by the authors.

Table 11. Civil and Political Freedoms Index.

\begin{tabular}{lc}
\hline Year & Freedoms index \\
\hline 2001 & 4 \\
2002 & 5 \\
2003 & 5 \\
2004 & 5 \\
2005 & 4 \\
\hline
\end{tabular}




\begin{tabular}{cc}
\hline 2006 & 4 \\
2007 & 4 \\
2008 & 4 \\
2009 & 5 \\
2010 & 6 \\
2011 & No information available \\
2012 & 6 \\
2013 & No information available \\
2014 & 5 \\
2015 & 5
\end{tabular}

*Source: UNDP 2015.

agriculture, land and construction, phosphate and potash and workers in Aqaba Port

2) Tribal and clan movements, such as movement of Bany Hassan, Bany Sakhr, Da'jah, Alhjaya, and Ayasrah

3) Regional movements, including Freemen of Tafila, Al-Tafayla neighbourhood in Amman, Karak movement, Theban movement, Amman Freemen and Ramtha movement

4) Partisan and trade union movements, in particular Islamic Action Front, the left parties, the journalists' union, and unions of artists, engineers, lawyers and teachers

5) National movements, including Constitutional Monarchy Movement, the movement of the Constitution of 1952, the Jordanian initiative for reform, the Jordanian National Movement, and Movement 36

6) Youth movements, and especially March 24 movement, April 5 movement, the youth movement, Jayen (We are coming) Movement and Thabahtona (You are killing us) Movement (students' rights)

Violence and protesting behavior was widespread, due to the emergence of multiple labor, professional, regional, youth and national movements, which amounted to 130 movements in 2011. Labor protests grew from 139 to 691 in the second quarter of 2011. Likewise, the incidents of communal violence escalated to the so-called "university violence" resulting in declination in the role of parties in political participation. This is evident in the $51 \%$ rise in the youth participation in the political life on grounds of categorical and national demands, such as protesting against the increase in the oil derivative prices and fighting against corruption, making most of such movements based on unorganized interests based on nepotism, or geographic considerations, or temporary interests that took the form of turmoil, sit-ins and riots [26].

Due to the two aforementioned indices, the political participation index was rated as strong, with the score of 1 . However, their outcomes and influence on 
the political regime were undermined due to the fact that it was controlled by categorical, regional and social demands.

\subsubsection{Government Stability Index}

The UNDP established an index to reflect the government effectiveness. It encompasses many variables, including bureaucracy quality, the quality of health care and government stability. The scale ranges from -2.5 to +2.5 , with higher values pertaining to better quality. Most of the scores of Effectiveness of the Government of Jordan were less than 1 (Table 12).

Considering the government stability variable, with the formation of governments and ministerial reshuffling as sub-variables to the government effectiveness, government instability is noticeable as shown in Table 13.

Reviewing the tabulated data, the researchers highlight that there was ministerial reshuffling every 9.1 months on average and that the rate of formation of government was once per 7 months during the 27 years in the 1989 to 2016 period. Therefore, the researchers score the government stability index with its two variables with a numerical value of zero, due to its considerable weakness. The government instability and weak governmental elite circulation may be attributed to assigning the political positions on the basis of geographic and social influence.

\subsubsection{Parliamentary Stability Index}

In order to score this index, the researchers assessed the legislative role of the Parliament via the queries, interrogations and effectiveness of performance through the cohesion of the internal structure (parliamentary blocs).

The researchers noted that seven parliaments were formed since the beginning of the democratic transition and Socioeconomic Transformation Program. Three of those were dissolved in 2003, 2007 and 2010, respectively. This is indicative of a high parliamentary instability. The dissolution was accompanied by an amendment or change of the Electoral Law, increasing the number of MPs throughout the period $1989-2016$ to $80 / 110 / 120 / 150$ respectively, with female

Table 12. The Government Effectiveness 2002-2009.

\begin{tabular}{cc}
\hline Year & Government effectiveness \\
\hline 2002 & 0.2 \\
2003 & 0.25 \\
2004 & 0.16 \\
2005 & 0.1 \\
2006 & 0.19 \\
2007 & 0.27 \\
2008 & 0.27 \\
2009 & 0.28 \\
\hline
\end{tabular}

^Source: UNDP of 2010. 
Table 13. Governmental Reshuffle in Jordan 1989-2014.

\begin{tabular}{|c|c|c|c|c|c|c|c|c|}
\hline Prime Minister & $\begin{array}{c}\text { Date of } \\
\text { formation }\end{array}$ & $\begin{array}{l}\text { Number of } \\
\text { Ministers }\end{array}$ & $1^{\text {St }}$ reshuffle & $\begin{array}{c}2^{\text {nd }} \\
\text { Reshuffle }\end{array}$ & $\begin{array}{l}3^{\text {th }} \\
\text { reshuffle }\end{array}$ & $\begin{array}{c}4^{\text {th }} \\
\text { Reshuffle }\end{array}$ & $\begin{array}{l}\quad 5^{\text {th }} \\
\text { Reshuffle }\end{array}$ & $\begin{array}{c}\text { Date of } \\
\text { resignation }\end{array}$ \\
\hline Zaid Bin Shaker & $1989 / 4 / 27$ & 24 & $1989 / 9 / 2$ & - & - & - & - & $1989 / 12 / 26$ \\
\hline MudarBadran & $1989 / 12 / 7$ & 24 & $1990 / 6 / 19$ & $1991 / 1 / 2$ & - & - & - & 1991/6/19 \\
\hline Taher al-Masri & $1991 / 6 / 20$ & 24 & $1991 / 10 / 24$ & - & - & - & - & $1991 / 11 / 20$ \\
\hline Zaid Bin Shaker & $1991 / 11 / 21$ & 24 & - & - & - & - & - & $1993 / 5 / 29$ \\
\hline Abdul Salam Majali & $1993 / 5 / 30$ & 27 & $1993 / 10 / 15$ & $1993 / 12 / 2$ & $1994 / 6 / 8$ & - & - & $1995 / 1 / 7$ \\
\hline Zaid Bin Shaker & $1995 / 1 / 8$ & 31 & - & - & - & - & - & $1996 / 6 / 4$ \\
\hline Abdel Karim Kabariti & $1996 / 2 / 4$ & 30 & $1996 / 2 / 4$ & - & - & - & - & $1997 / 3 / 19$ \\
\hline Abdul Salam Majali & $1997 / 3 / 19$ & 24 & $1998 / 2 / 7$ & - & - & - & - & $1998 / 8 / 20$ \\
\hline Fayez Tarawneh & $1998 / 8 / 21$ & 23 & $1998 / 11 / 1$ & - & - & - & - & $1999 / 3 / 4$ \\
\hline Abdel Raouf Rawabdeh & 1999/3/4 & 23 & 1999/9/1 & $2000 / 1 / 15$ & $2000 / 5 / 1$ & - & - & $2000 / 6 / 18$ \\
\hline Ali Abul Ragheb & $2000 / 6 / 19$ & 29 & $2000 / 9 / 26$ & $2000 / 6 / 16$ & $2001 / 9 / 2$ & $2001 / 10 / 27$ & $2000 / 12 / 5$ & $2002 / 1 / 14$ \\
\hline Ali Abul Ragheb & $2002 / 1 / 14$ & 27 & $2002 / 3 / 24$ & $2002 / 9 / 26$ & $2003 / 1 / 12$ & $2003 / 1 / 13$ & - & $2003 / 7 / 20$ \\
\hline Ali Abul Ragheb & $2003 / 7 / 21$ & 29 & - & - & - & - & - & $2003 / 10 / 22$ \\
\hline Faisal al-Fayez & $2003 / 10 / 25$ & 21 & $2003 / 10 / 25$ & $2005 / 2 / / 20$ & - & - & - & $2005 / 4 / 5$ \\
\hline Adnan Badran & $2009 / 4 / 7$ & 26 & $2005 / 7 / 3$ & - & - & - & - & $2005 / 11 / 24$ \\
\hline Marouf Bakhit & $2005 / 11 / 27$ & 24 & $2006 / 10 / 22$ & $2007 / 9 / 2$ & - & - & - & $2007 / 10 / 22$ \\
\hline Nader Dahabi & $2007 / 10 / 25$ & 28 & $2009 / 2 / 23$ & $2009 / 6 / 11$ & - & - & - & $2009 / 12 / 9$ \\
\hline Samir Rifai & $2009 / 12 / 14$ & 29 & $2010 / 7 / 28$ & $2010 / 10 / 26$ & - & - & - & $2010 / 11 / 22$ \\
\hline Marouf Bakhit & $2011 / 7 / 2$ & 27 & - & - & - & - & - & $2011 / 10 / 17$ \\
\hline Awn Khasawneh & $2012 / 4 / 9$ & 30 & - & - & - & - & - & $2012 / 4 / 26$ \\
\hline Fayez Al-Tarawneh & $2012 / 5 / 3$ & 31 & - & - & - & - & - & $2012 / 10 / 10$ \\
\hline Abdullah Nsour & $2012 / 10 / 11$ & 20 & $2013 / 3 / 30$ & - & - & - & - & $2016 / 5 / 29$ \\
\hline Hani Al-Molqi & $2016 / 5 / 29$ & 29 & - & - & - & - & - & - \\
\hline
\end{tabular}

*Source: The Cabinet website http://www.pm.gov.jo/amabic.

quota starting from 6 women MPs to 12, in addition to increasing the quota for minorities (Christians, Circassians, Chechens and Bedouins). This has led to weakened party representation in the parliamentary elite, attracting them instead to their regional and tribal roots [27]. Consequently, individual performance prevailed typified by lack of cohesion of the parliamentary blocs in terms of the high rate of formation and disintegration based on personal alliances competing for membership of the Permanent Bureau of the Parliament and chair of the parliamentary committees.

Table 14 presents the accomplished laws as a legislative dimension of the Parliament and the number of queries, interrogations, requests for discussion, motions of desire/law, petitions, complaints and memos:

Reviewing the information tabulated above, the researchers have the following 
Table 14. Scrutiny and Legislative Dimensions of the $15^{\text {th }}$ and $16^{\text {th }}$ Parliaments.

\begin{tabular}{lccccccccccccccc}
\hline Queries & Interrogations & $\begin{array}{c}\text { Requests } \\
\text { for } \\
\text { discussion }\end{array}$ & \multicolumn{2}{c}{$\begin{array}{c}\text { Motions } \\
\text { of desire }\end{array}$} & $\begin{array}{c}\text { Motions } \\
\text { of law }\end{array}$ & $\begin{array}{c}\text { Petitions \& } \\
\text { complaints }\end{array}$ & Memos & Laws \\
\hline MPs & MPs & MPs & MPs & MPs & MPs & MPs & MPs & MPs & MPs & MPs & MPs & MPs & MPs & MPs & MPs \\
15 & 16 & 15 & 16 & 15 & 16 & 15 & 16 & 15 & 16 & 15 & 16 & 15 & 16 & 15 & 16 \\
467 & 751 & 10 & 15 & 10 & 8 & 5 & - & 10 & 30 & 7 & 26 & 226 & 320 & 116 & 78 \\
\hline
\end{tabular}

*Source: National Assembly of Jordan.

remarks on the parliamentary performance:

1) The legislative dimension prevailed over the scrutiny dimension as represented by 25 interrogations.

2) Low level of responsiveness of the Parliament to citizens was evident, represented by the requests for discussion, petitions and complaints, of which here were 20 in the $15^{\text {th }}$ Parliament and 34 in the $16^{\text {th }}$ Parliament. On the grounds of these findings, the researchers give a score of zero as the numerical value for the Parliamentary Performance Index due to it being weak.

\subsubsection{Transparency Index}

The transparency index witnessed fluctuation during the stage of democratic transition in Jordan with the beginning of the economic reform program, with more frequent declines than increases. In 2010, Jordan was ranked $50^{\text {th }}$ among 178 countries, after being ranked $47^{\text {th }}$ in 2009 . Jordan maintained $5^{\text {th }}$ position among Arab countries and further progressed to $3^{\text {rd }}$ in 2014 [28].

Table 15 below shows Jordan ranks and rates as per the Corruption Index from 2000 to 2014 based on Transparency International (TI) report of 2014.

The Corruption Control is scored on a scale ranging from -2.5 to +2.5 , with higher values indicating lower corruption. The UNDP report showed that Jordan maintained a value of less than one throughout the period (2000-2009) [29], thus the researchers give an average score of 0.5 to Jordan's transparency index (Table 16).

\section{Tested Hypotheses}

The researchers note that the six variables of economic reform had strong quantitative impact on the political pluralism index, i.e., the increased number of political parties, reaching 43 parties in 2016. The extent of change in the political pluralism index may be deemed average based on the increased rate of change of the Parties Law and Electoral Law, where the Parties Law was changed in 1999/2007/2012/2016 and the Electoral Law was changed in 1989/1993/2007/2012/2016. They also note that economic reform had only limited impact on the political reform according to the civil and political freedoms index released by the UNDP in 2010, where Jordan was rated as a partly-free country. The researchers observe that economic reform had strong impact on the political participation index in terms of the emergence of social forces expressing their disapproval of the performance of 
Table 15. Jordan Ranks and Rates of Corruption Index.

\begin{tabular}{cccc}
\hline Year & Rank & No. of countries & Rate \& value \\
\hline 2000 & 39 & 90 & 4.6 \\
2001 & 37 & 91 & 4.9 \\
2002 & 40 & 102 & 4.6 \\
2003 & 43 & 133 & 3.5 \\
2004 & 37 & 145 & 5.7 \\
2005 & 37 & 158 & 5.3 \\
2006 & 40 & 163 & 4.7 \\
2007 & 53 & 179 & 5.1 \\
2008 & 47 & 180 & 5.0 \\
2009 & 49 & 180 & 4.7 \\
2010 & 50 & 185 & - \\
2011 & 36 & 183 & 4.5 \\
2012 & 58 & 76 & 4.8 \\
2013 & 66 & 175 & - \\
2014 & 55 & 175 & 5.3 \\
2015 & 45 & - & \\
\hline
\end{tabular}

*Source: Transparency International reports.

Table 16. Total values of the economic and political indices.

\begin{tabular}{|c|c|c|c|c|}
\hline No. & Economic index & Value & Political index & Value \\
\hline 1 & $\begin{array}{l}\text { Average annual per capita } \\
\text { income }\end{array}$ & Average (0.5) & Political pluralism & Average (0.5) \\
\hline 2 & $\begin{array}{l}\text { Altered class structure } \\
\quad \text { (middle class) }\end{array}$ & Weak $(0)$ & Public freedoms & Average (0.5) \\
\hline 3 & Urbanization rate & Average (0.5) & Political participation & Strong (1) \\
\hline 4 & Degree and level of education & Average (0.5) & Government stability & Weak $(0)$ \\
\hline 5 & Degree of industrialization & Weak $(0)$ & $\begin{array}{l}\text { Parliamentary } \\
\text { performance }\end{array}$ & Weak (0) \\
\hline 6 & $\begin{array}{l}\text { Extent of spread of social media } \\
\text { (information technology) }\end{array}$ & Average (0.5) & Transparency & Average (0.5) \\
\hline 7 & General Average & Average (0.5) & General Average & Average (0.5) \\
\hline
\end{tabular}

Source: this table was made by the authors.

the Jordanian political regime, emergence of violence and protesting behavior. It is noteworthy, however, that political participation was categorical or regionally based, and we conclude that economic reform had a weak impact on government stability. Government effectiveness maintained a value $<1$ with frequent ministerial reshuffling, whereby 21 governments have been formed since 1989 since the economic reform program commenced. This is equivalent to an average of one reshuffle per 7-month interval over 27 years from 1989 to 2016. The 
researchers thus note that economic reform had a weak impact on the level of parliamentary stability and performance as evidenced by the fact that the legislative dimension prevailed over the scrutiny function and a weak responsiveness of the parliament to people's demands by submitting requests for discussion, petitions and complaints. Furthermore, the parliament was dissolved on three occasions, in 2003, 2007 and 2010. The researchers finally conclude that economic reform had an average impact on the transparency level, whereby Jordan maintained scores $<1$ throughout the 2000-2009 period. The corruption index was generally on the rise.

\section{Results}

This article explores the interactions between economic and political reforms in Jordan. Over the past two decades, there have been significant moves towards economic and political reforms in Jordan, but without taking important steps towards democratic government, and reform efforts have failed to address the major economic and political problems affecting the majority of the Jordanian citizens, and reform efforts face severe resistance from elites who benefit from the status quo.

The article reached a set of results, which claim firstly that four of the six indices of economic reform were average, with a score of 0.5 , and the other two were weak, with a score of zero. The general average of all six indices is therefore average, while three indices were average with a score of 0.5 , one index was strong with a score of 1 , and two indices were weak with a score of zero. The general average of all six indices of political reform is therefore average. Another notable result is the increased strength of the political participation index, which was scored as 1 for being strong. This is attributed to the Arab revolutions starting in 2011 along with greater employment of the non-traditional means of political participation such as public, regional, tribal and demand-based protests, thus undermining its impact. There was also the result of reviewing the general average of the economic reform indices and of the political reform. A moderate association can be noted between the impacts of economic reform indices and the dependent variable of political reform. We can thus posit that the political regime in Jordan is semi-free, having flawed and restricted democracy that has not yet reached the status of a mature and full democracy. This assertion is based on the average values of the economic reform indices and political reform indices. The weak scores of economic indices have negatively affected the political reform indices, while the quantitative increase in the economic indices is not necessarily a proof of their positive impact on the political indices. Thus, the correlation between the indices themselves and the qualitative dimension must be considered.

\section{Support}

This research was partially supported by Deanship of Scientific Research and Graduate Studies at Yarmouk University. 


\section{References}

[1] Jordanian Ministry of Planning and International Cooperation. (2017) SETP Background-Reforms: 1989-1999. http://www.mop.gov.jo

[2] Al-Sayid, A. (2000) Political Participation. Political and Strategic Studies Center, Cairo. (In Arabic)

[3] Bani Salameh, M. (2018) Political Reform in Jordan: Reality and Aspirations. World Affairs Journal, 180, No. 4. https://doi.org/10.1177/0043820018765373

[4] Ebied, H. (2013) International Conditionality and Political Reform: Egypt. International Politics, 191, 90-95. (In Arabic)

[5] Lipset, S. (1959) Some Social Requests of Democracy: Economic Development and Political Legitimacy. American Political Science Review, 53, 69-105. https://doi.org/10.2307/1951731

[6] Colman, J. (1960) The Political Systems of the Developing Areas. Princeton University Press, Princeton, 532-581.

[7] Pye, L. (1966) Aspects of Political Development: An Analytical Study. Little Brown, Boston.

[8] Deutsch, K. (1966) Nationalism and Social Communication: An Inquiry into the Foundation of Nationality. MII Press, Cambridge.

[9] Learner, D. (1958) The Passing of Traditional Society. Free Press, New York.

[10] Russett, B. (1993) Grasping the Democratic Peace: Principles for a Post-Cold War World. Princeton University Press, Princeton, 100-105.

[11] Neabauer, D. (1967) Some Social Conditions of Democracy. Political Science Review, 61, 1002-1009.

[12] Doucouliagos, H. and Ulubasoglu, M.A. (2008) Democracy and Economic Growth: A Meta-Analysis. American Journal of Political Science, 52, 61-83. https://doi.org/10.1111/j.1540-5907.2007.00299.x

[13] Moton, H. (2004) The Democracy Advantage: How Democracies Promote Prosperity and Peace. Routledge Publishers, New York, NY, 105.

[14] Sen, A. (2000) 1933-Development as Freedom. Anchor Books, New York.

[15] Aljezawi, B. (2013) The Impact of Economic and Social Transformation on the Political Development in Jordan (2001-2012). Yarmouk University, Jordan, 49-52. (Unpublished Master Thesis, in Arabic)

[16] Khasawneh, M. (2003) The Impact of the Programs of International Financial Institutions on State Sovereignty: Comparative Study between Jordan and Egypt. Cairo University, Cairo, 171-180. (Unpublished Master Thesis, in Arabic)

[17] Diamond, L. (2001) How People View Democracy Findings from Public Opinion Surveys in Four Regions. Paper Presented to the Stanford Seminar on Democratization, 11 January.

[18] Brouce, R. (2001) The Relationship between Democracy \& Development. Almanar, Amman, 12-14. (In Arabic)

[19] The Economist. (2017) Democracy Index 2014. http://wwww.eiu.com\.publicltopical report.aspx? campaignid=Democracy0115

[20] Mohammed, T., Salameh, B. and Shdouh, E. (2018) Feminist Elites in Democratic Jordan 1989-2016. In: Alagan, R. and Aladwaka, S., Ed., Environment, Politics, and Society (Research in Political Sociology, 25), Emerald Publishing Limited, West Yorkshire, 181-201. 
[21] Jordanian Department of Statistics. (2015) National Exports Down. http://web.dos.gov

[22] Bani Salameh, M. (2017) Political Reform in Jordan: Reality and Aspirations. World Affairs Journal, 180, No. 4. https://doi.org/10.1177/0043820018765373

[23] Al-Massawi, M. (2014) The Concept of Freedom in Contemporary Islamic Thoughts. Tabyen, 2, 59-66. (In Arabic)

[24] Bani Salameh, M. and Aananzah, A.A. (2015) Constitutional Reforms in Jordan: A Critical Analysis. Digest of Middle East Studies, 24, 139-160.

https://doi.org/10.1111/dome.12068

[25] Bani Salameh, M. and Darawsheh, S. (2018) Human Rights in the Jordanian Constitution: Between Theoretical Texts and Practical Application. International Journal of Human Rights and Constitutional Studies, 6. https://doi.org/10.1504/IJHRCS.2018.091658

[26] Daradkeh, M. (2014) The Impact of Arab Spring: Challenges \& Setbacks. Jordanian University, 18-20. (Unpublished Master Thesis, in Arabic)

[27] Bani Salameh, M. and Eledwan, K. (2016) The Identity Crisis in Jordan-Historical Pathways and Contemporary Debates. Nationalities Papers, 44, No. 6. https://doi.org/10.1080/00905992.2016.1231454

[28] Al-Dostur Newspaper, February 23rd 2014.

[29] Al-Faisal, M. (2001) The Arabs and the Asian Experience. Economic Studies, 4, 122-125. (In Arabic) 